\title{
Village Networks: The Small World of Fourth-Century Kellis
}

No family is an island unto itself. For the Pamour family, the village of Kellis was one of the primary arenas of their social life, one where they interacted with larger social entities based on kinship alliances, economic activities, political institutions, and religious practices. The current chapter examines the family's position within this village world, taking a relational approach. What sort of influence did the family wield? Who were their close associates? How did they interact? These questions are of relevance to the questions that will preoccupy us in Chapter 6, namely the extent of the local Manichaean community and the social networks in which affiliation with it spread.

Unfortunately, the Pamour archive itself presents something of an obstacle to gaining a proper sense of the family's position. The archive looms large among the papyri from the village, its bulk painting a picture in which family members appear more prominent than they in were. Luckily, fourth-century papyri from other find sites do widen our perspective, and the House 1-3 material itself contains documents that pertain to larger village concerns, which together can help to correct this Pamour-centric picture. They reveal other circles of villagers with whom the Pamour family interacted: their neighbours in House 2, Oasis notables who may have acted as patrons, and fellow-traders in Kellis and on the Nile who formed their primary business associates. In the course of this chapter, we shall examine the prosopography, role, and relationship to the Pamour family of these various groups. We conclude with a quantitative network analysis based on the textual material, using the whole spectrum of documentary papyri from the village in order to map the social circles of fourth-century Kellis.

First, however, there are some documents that could provide more direct clues as to the family's position. For one, the family is known to have served as liturgists in the local administration, attested in P.Kellis I Gr. 72 where Horos III is said to have been appointed to a liturgy. Unfortunately, the author of this letter, Pekysis, neglects to mention the nature of the liturgy. In itself, then, it does not tell us much about their wealth and status, apart from that they belonged to the (rather large) upper segment of villagers who were obliged to perform such service. ${ }^{1}$ More promising are two expense accounts dating to the first half

1 Bagnall, Egypt in Late Antiquity, 135-36.

(C) HÅKON FIANE TEIGEN, 2021 | DOI:10.1163/9789004459779_005

This is an open access chapter distributed under the terms of the CC BY-NC-ND Ato license. Teigen - 9789004459779 
of the fourth century, P.Kellis I Gr. 53 and 54, which could point to a higher level of responsibility. ${ }^{2}$ They list payments for a range of expensive services of a public nature. P.Kellis I Gr. 53 includes entries of payment for a teacher brought from the Nile Valley, translation services, and for a prinkipos, probably the 'chief of staff' of the governor in the Thebaid. P.Kellis I Gr. 54 features a rhetor, a messenger, and a shorthand writer, and Worp proposes to restore one line as referring to an order from the office of the strategos. ${ }^{3}$ Such expenses may be taken to imply that the document belonged to a prominent local official. Unfortunately, we cannot be certain that they belonged to the Pamour family. Other possible owners are Ploutogenes son of Ouonsis and Pausanias (for whom, see below). No other document mentions a member of the family holding such office, and other evidence from the same period on the contrary indicates that they had trouble with local officials. In a petition dated 321, P.Kellis I Gr. 21, Pamour I lodged a complaint concerning longstanding trouble with a komarch, Sois son of Akoutis. This man was stirring up local soldiers and military officials against him, and finally broke into his house and assaulted his wife. Perhaps this conflict was part of a larger power struggle between different fractions in the village, but this remains unknown. At any rate, the family is unlikely to have been among the most powerful villagers, as will also be seen in the analysis below.

\section{Meet the Neighbours}

Let us turn to the people with whom the Pamour family had more friendly relations, starting with the Pamour family's closest associates - in a literal, physical sense. The Pamour family was not the only inhabitants of the House 1-3 complex. Texts found in the neighbouring structure, House 2, pertain to two circles, both centred on carpenters: the Ploutogenes circle and the Tithoes family. That one or both of the carpenters inhabited House 2 is made likely by the discovery of carpentry tools and -materials there. ${ }^{4}$ The papyri themselves provide support, in the form of prosopographic ties between these circles and House 3, as we shall see.

2 The sum of money paid for the teacher in P.Kellis I Gr. 53 points to a date in the first half, as does the (restored) occurrence of the strategos in P.Kellis I Gr. 54, although it should be noted that this term was still in use in the Oasis in 352 , per P.Kellis I Gr. 23.

3 See the notes in P.Kellis $I, 152,154$.

4 Colin A. Hope, 'The Find Context', in The Kellis Agricultural Account Book, ed. Roger S. Bagnall (Oxford: Oxbow, 1997), 9. 
The earliest of the two circles in House 2 is that of the carpenter Ploutogenes son of Petesis. The documents pertaining to him relate to his business correspondence with two local grandees: Pausanias in P.Kellis I Gr. 5 and 6 (33os?) and Harpokration in P.Kellis I Gr. 7 (c.35o?). ${ }^{5}$ The former is known to be an acquaintance of the Pamour family, and Ploutogenes acted as an agent on his behalf (see below). His father, Pataias, appears in several documents: as a signatory to two declarations, P.Kellis I Gr. 3 and 24, and as associate of a certain Aionianos and his father Gelasios in P.Kellis I Gr. 16. Ploutogenes and his father appear to have been prominent figures in the second quarter of the fourth century, not least because Pausanias, Harpokration, Gelasios, and Aionianos can all be shown to have been ex-magistrates.

Ploutogenes also interacted with the Pamour family: he is the only witness in P.Kellis I Gr. 76, where he vouches for the trustworthiness of Pekysis son of Psais II. The document was found in House 3, and is of a much later date than those from House 2 (perhaps the 37os). Beyond that, the nature of Ploutogenes' relationship with House 3 is obscure. A few associates (mostly colleagues) occur in the above-mentioned documents, but none can be identified in the House 3 circles. Without such supporting evidence, further identification of this figure with any of the homonymous men in the House 3 texts remains speculative. Yet, these documents do provide circumstantial evidence for long-standing relations with the people of House 3 .

The second House 2 group can be described in more detail. It, too, is centred on a carpenter, a man named Tithoes (I) son of Petesis. The material relating to him includes five Greek texts, P.Kellis I Gr. 8-12, and one in Coptic, P.Kellis v Copt. 12. Of these, the letters P.Kellis I Gr. 12 and P.Kellis v Copt. 12, exchanged between Tithoes I and his son Samoun, provide insight into Tithoes I's familial circle. It included Samoun and his son, Tithoes II, several sisters greeted by or send greetings to Samoun, such as Tsenpamoun, Tapshai, and Tehat, as well as a couple, 'brother' Psenpnouthes and 'sister' Kyria. To what extent these are literal siblings of Samoun is unclear. Tithoes I himself did have a biological sister, married to the son of a camel driver named Horos son of Mersis, documented by the inheritance contract P.Kellis I Gr. 9. The names of both the sister and her husband are lost, but Horos son of Mersis was another neighbour, known from documents found in House 3 (see below).

5 In contrast to among others Nevett ('Family and Household', 21), I take it that Ploutogenes, not Pausanias, should be identified as the owner of their correspondence. This is based on the additional find of P.Kellis I Gr. 7, pertaining to Ploutogenes, in close proximity to P.Kellis I Gr. 6, as well as on the find of documents relating to Pausanias elsewhere in the village. 
How Tithoes I was linked with Ploutogenes is unclear, although their shared occupation is unlikely to be a coincidence. His activities belong to a later date, to the second half of the fourth century. Only one text pertaining to Tithoes I with a consular date is preserved, P.Kellis I Gr. 8 dating to 362 , but two other documents point in the same direction: P.Kellis I Gr. 10, a memo addressed to Tithoes I, can be dated to $368 / 9,{ }^{6}$ while P.Kellis I Gr. 11, a similar memo to his son Samoun, belongs to the later part of the fourth century. ${ }^{7}$ This would lead us to expect a close relationship between Tithoes I and the House 3 circles. Numerous prosopographic links between them bear this out. ${ }^{8}$ Thus, the couple Psenpnouthes and Kyria, who greet Samoun, recur in both the Maria/Makarios and the Pamour/Pekysis circle. And while Samoun is absent, the name Tithoes occurs in several Pamour letters. ${ }^{9}$ Its popularity in Kellis means that an identification with Tithoes I or II cannot be taken for granted. Yet, the presence of 'father' Tithoes in a letter by Tapsais to Psais III, P.Kellis VII Copt. 116, strongly supports an identification of both these two with their namesakes in the Tithoes family. The name Tapsais, in fact, recurs frequently in the texts from House $3 .{ }^{10}$ It is clear that the two families cultivated close social ties; ties that may have involved economic cooperation, as members of the Tithoes family engaged in textile work and travelled to the Nile Valley. Carpentry must have provided an important venue for cooperation with the Pamour family as well, in the case of both Tithoes I and Ploutogenes. The many wooden codices found in House 3, some of which we touch on in Chapter 7 , point in this direction.

6 The sum of 800 T. for an artaba barley, combined with a mark for the twelfth indiction year, places it in either $368 / 9$ or $383 / 4$ (P.Kellis I, 34). Considering the date of P.Kellis I Gr. 8 , and the barley prices found in the КАВ and P.Bingen $120,368 / 9$ is the most plausible date.

$7 \quad$ No date is preserved, but Samoun is now recipient, and there has been a steep price increase, from 800 T. to 2000 T. per art. barley. This is much higher than that found in other texts of the 3605 , and this document, then, probably belongs to the 370 or or 380 . For inflation in this period, see Bagnall, Currency and Inflation, 46-47.

8 Of the 14 relatives/associates in the letters of Tithoes I (P.Kellis I Gr. 10-12; P.Kellis v Copt. 12), ten recur in the House 3 circles: Tithoes, Tapsais, Tehat, Tbeke, Pebok, Psenpnouthes, Kyria, Andreas, Makarios, and Ammon, to which we can add their mutual relationship with Horos son of Mersis (see below).

$9 \quad$ P.Kellis viI Copt. 70, 72, 77, and 116. Of these, only Tithoes 'of Peiaune' in P.Kellis viI Copt. 77 is very unlikely to pertain to the family of Tithoes I ; see P.Kellis VII, 104.

10 While there were two figures named Tapsais (see P.Kellis viI Copt. 65), one of them, here labelled Tapshai II, should be taken as the 'sister' of Samoun. The figure of Lammon provides an important link, as he is closely linked with the names Tapshai and/or Tithoes on several occasions: P.Kellis v Copt. 19; P.Kellis viI Copt 65, 70, and 116. 
Moreover, weavers in antiquity depended on carpenters for their tools, and weaving utensils were found alongside the carpentry tools in House $2 .{ }^{11}$

Finally, another neighbour was the camel driver Horos son of Mersis. He may not have lived in House 1-3, but he did own a camel stall adjacent to the house of Psais II, as recorded in P.Kellis I Gr. 38, dating to 333. Horos may well have been a man of some means: camel stalls were usually expensive to maintain. ${ }^{12}$ Nor was he 'merely' the owner of neighbouring property: as mentioned above, a son of his married into the family of Tithoes I. Moreover, two freight receipts, P.Kellis I Gr. $5^{1}$ and 52 , point to close ties to the Pamour family. Both date from $c .320$, were found in House 3 , and relate to goods Horos had transported to Hermopolis in the Nile Valley. ${ }^{13}$ Their discovery in House 3 strongly suggests that the family had a stake in his trips. It is unlikely to be a coincidence that Pamour I is known to have engaged transport to Hermopolis in the same period: the location of Horos' camel stall would have made good practical sense if he and the Pamour family cooperated in trade.

From these documents, we catch glimpses of the complex weave of relationships that were formed in the House 1-3 complex, as neighbouring families socialised, worked together, and intermarried. Ties extended across housing units and occupational backgrounds. As we shall see in Chapter 6, this has important implications for our understanding of the spread of religious affiliation in the village.

While the neighbourhood was an important unit for social interaction and cooperation, the family was not limited to its immediate social peers. Several documents show that the Pamour family's social network included notables and ex-magistrates of some note, even figures who wielded influence over the whole Great Oasis. Not least, these are, on occasion, found to have interacted directly with actors known from the House $1-3$.

11 Ewa Wipszycka, L'industrie textile dans l'Egypte Romaine (Wrocław: Wyadawnictwo Polskiej Akademii Nauk, 1965), 51-52. For the House 2 finds, see Hope, 'The find context', 9 .

12 Adams, Land Transport, 89. The name 'Horos son of Mersis' is found as owner of an orchard in an ostrakon from Trimithis, O.Trimithis I 241, dating to the late third-early fourth century (see the comments of Bagnall and Ruffini, Ostraka from Trimithis, 30). If this is the same man, he clearly had far-flung interests in the Oasis. He would also be quite old by the time of P.Kellis I Gr. 38 .

13 His name and the dating formula have to be restored in the former, see P.Kellis I, 148-49. 
While petitioning the governor over a conflict with Pollon son of Psais in P.Kellis I Gr. 20 (dating c.300-320), Pamour I received the support of a man named Phibion, an ex-magistrate of Hermopolis. ${ }^{14}$ Nothing more is heard of Phibion, but it clearly shows that the family had ties to notables in the Valley at an early date, perhaps of patronage. More can be said about their ties to a local notable named Pausanias. He is known from several Greek texts from House 2 and 3: three letters, P.Kellis I Gr. 5, 6 (House 2), 63 (House 3), and two contracts, P.Kellis I Gr. 4 (House 2) and 38 (House 3). The contracts are dated 331 and 333, respectively. P.Kellis I Gr. 38 preserves Pausanias' patronym, 'son of Valerios', and his title, ex-magistrate of Mothis, showing that he had served as magistrate already by 333. Furthermore, texts from other parts of Kellis provide additional information. While Pausanias' office is unspecified in P.Kellis I Gr. 38, a petition to Pausanias found in the structure D/8, P.Gascou 69, specifies them as riparius and exactor. ${ }^{15}$ This riparius/exactor can be confidently identified with the man in P.Kellis I Gr. 38, as another papyrus also from D/8, the official letter P.Gascou 71 (dated 336/7), is addressed specifically to Pausanias son of Valerios. The contracts from House 2 and 3 evidence close ties between this man and the Pamour family. P.Kellis I Gr. 4 is unfortunately very fragmented,

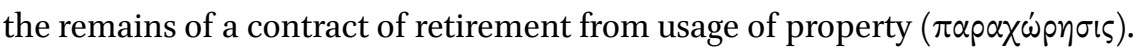
Pausanias here hands over property to a figure whose name is lost, but which could well be restored as Pamour. ${ }^{16}$ More secure is P.Kellis I Gr. 38 , a similar contract for the grant of property by Pausanias. Here the name of the recipient is well-preserved: Psais (II), son of Pamour (I). The background for this gift is not mention, but it suggests that Pausanias acted as a patron to Psais II (see Chapter 6, Section 2.4). Interaction between them must have gone beyond this grant, as the text also mentions that Pausanias owned other properties neighbouring on Psais II's house. The other documents from House 2 and 3 provide further indications of a strong relationship to their inhabitants. These are all private letters, and so Pausanias is not furnished with either patronym or official title, but there is little reason to doubt that they involve the same man. In P.Kellis I Gr. 6, from Ploutogenes to Pausanias, the former styles the

\footnotetext{
14 For the name of the assailant, see Jean-Luc Fournet, 'Notes critiques sur des pétitions du Bas-Empire', The Journal of Juristic Papyrology 28 (1998): 8-10; Nikolaos Gonis, 'Notes on Miscellaneous Documents', Zeitschrift für Papyrologie und Epigraphik 143 (2003): 160-61.

15 This information was first provided by Worp, cited in Colin A. Hope, 'Excavations in the Settlement of Ismant el-Kharab: Five Field Seasons 1995-1999', in Dakhleh Oasis Project: Preliminary Reports on the 1994-1995 to 1998-1999 Field Seasons, ed. Colin A. Hope and Gillian E. Bowen (Oxford: Oxbow, 2002), 202-4. The papyrus was subsequently published in Worp, 'Miscellaneous New Papyri'.

16 As suggested in P.Kellis I, 2o. If correct, this is probably Pamour I, son of Psais I.
} 


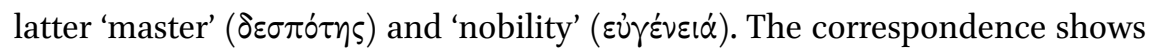
that Ploutogenes acted as an agent for Pausanias, performing errands on his behalf together with other agents. The letter P.Kellis I Gr. 63 is of a rather different sort. It is written by a man whose name is lost, but who calls himself 'father', who addresses Pausanias and a certain Pisistratos as 'sons'. The kinship terms are clearly used in an extended sense, and several distinct religious cues point to the author being a Manichaean Elect (see Chapter 8, Section 2.3). It shows Pausanias to have been a Manichaean adherent, providing a point of commonality with the Pamour family. Unfortunately, the trail of their relationship does not go beyond the mid-fourth century. Pausanias does not surface in the Coptic texts, nor in other published Greek documents dated after the 340s. Pisistratos, a younger associate or relative of Pausanias, ${ }^{17}$ was still involved with people in Kellis in the 36 os. He does not occur in the Coptic texts, but is found helping one of the family's associates with a loan, in a contract datable to the later fourth century. ${ }^{18}$

Two other local notables had ties to Ploutogenes son of Pataias, but are not known to have interacted with the Pamour family, namely Gelasios and Harpokration. Gelasios, a contemporary of Pausanias, is featured in two documents from House 2, both from the circle of Ploutogenes. One, P.Kellis I Gr. 7, is a letter from Harpokration to Ploutogenes, where he greets 'brother' Gelasios; the other, P.Kellis I Gr. 16, a memo from a certain Aionianos to his 'father' Gelasios, ordering the delivery of dates to 'brother' Pataias (dated 329/30 or 344/5?). The name recurs in P.Kellis I Gr. 29 (dated 331), found in House 3, a receipt for transport of 'statues' ( $\dot{\alpha} \nu \delta \varepsilon[l] \alpha \dot{\alpha} \tau \omega \nu)$ to Alexandria. This Gelasios is titled ex-logistes, making him one of the (formerly) most important officials in the whole of the Great Oasis. But is he the same as the man in the House 2 texts? Bagnall and Ruffini have objected that Aionianos' order implies 'father' Gelasios to be an inferior, making an identification with the ex-logistes unlikely. ${ }^{19}$ However, there is other evidence that points to an identification. A contract from House 4 in Kellis, P.Gascou 67 (dated 368), features Aionianos, son of Gelasios, 'ex-magistrate of Mothis'. He is clearly identifiable with the man in P.Kellis I Gr. $16 .{ }^{20}$ That Aionianos had held office strongly suggests that his father Gelasios had, too, and that the associate of Pataias and Ploutogenes can

\footnotetext{
17 See O.Kellis I 85, where Pausanias orders chickens for his 'son' Pisistratos.

18 See P.Kellis I Gr. 46 (House 3 ) and the comments in P.Kellis I, 137-38. The name Pisistratos is rare for the Roman period, but recurs in Kellis for the later fourth century in P.Bingen 120 (366/7), O.Kellis I 85 and 287.

19 Bagnall and Ruffini, Ostraka from Trimithis, 37 n.2o.

20 Not least because the name 'Aionianos' does not seem to be attested outside of Kellis. No other occurrence was found in the Trismegistos database (per 10/9/2020). A possible
} 
be identified with this notable. Moreover, P.Gascou 67 shows that Aionianos owned land in the vicinity of Kellis, indicating that the family's engagement there was extensive. ${ }^{21}$ With regards to his ties to the House $1-3$ circles, however, little can be said with certainty. The discovery of the freight receipt P.Kellis I Gr. 29 in House 3 may suggest that members of the Pamour family performed work on his behalf, although the agents are unfortunately not named. Neither Gelasios nor Aionianos are otherwise found in the Coptic or other Greek texts from House $1-3 .{ }^{22}$

A previously discussed ex-magistrate, Harpokration, similarly had ties to House 2. He was the 'villain' of the petition P.Kellis I Gr. 23 who allegedly helped one of his employees escape liturgical duties and sent attackers against the komarchs. ${ }^{23}$ The petitioner, the komarch Ploutogenes son of Ouonsis, describes him as having considerable power locally $(\dot{\varepsilon} \pi \grave{i} \tau \dot{o}[\pi \omega \nu])$. On the other hand, his letter to Ploutogenes son of Pataias, P.Kellis I Gr. 7, suggests that he normally had more peaceful ties to the village. Here he politely requests a dalmation tunic, discusses some matters in lines that are unfortunately illegible in the letter body, and ends by cordially asking for Ploutogenes' orders in return. His family retained ties to the village and to House 2 : in 362 , his son Timotheos helped sign a sales contract, P.Kellis I Gr. 8, to which the later inhabitant of House 2, Tithoes I son of Petesis, was also a part. However, no direct ties to the Pamour family are found.

Finally, the family may have had ties to the landlord Faustianos son of Aquila. He was a contemporary of the Pamour family, and a landowner with extensive holdings in the vicinity of Kellis and elsewhere in the Oasis, as documented by the КАB, but probably resided in Hibis. The КАВ belonged to one of his managers. Its discovery in House 2 might suggest that his manager should be sought among the actors there, but no certain identification can be made. ${ }^{24}$ Yet, there is evidence for cooperation between the manager and House 3 circles in the codex. Tehat owes the manager cotton-weaving, and is paid for agape,

Manichaean background for the name was broached by Gardner, referred to by Worp in P.Kellis I, 46-47.

21 See also P.Gascou 82 (early fourth century) from the structure D/8. Still unpublished texts from D/8 may shed further light on the figure of Gelasios; see Worp, 'Miscellaneous New Papyri', 438.

22 However, note O.Kellis I 288, an order from Aionianos to his 'son' Makarios, found at the West Church.

23 He should probably also be identified with the 'lord father' Harpokration, asked for orders in P.Gascou 8o, a letter addressed to a local official named Petechon. Note P.Kellis I Gr. 69, from House 3, where a Petechon requests orders from a logistes, whose name is lost.

For a discussion of a possible identification, see P.Kellis IV, 224. 
while associates of the Pamours are paid for transport. ${ }^{25}$ These arrangements probably relate to ad hoc acts of cooperation, or contracted work, not employment. A 'landlord' ( $\gamma$ \&ov̂xos) also occurs in some Greek letters of the Pamour family archive, there are good reasons to identify him with Faustianos. ${ }^{26}$ These letters are addressed to or from a man named Elias, who worked as an agent for the landlord. Members of the Pamour family who feature in these letters may have done so, too, although in what capacity is most unclear. Still, Faustianos remained a distant figure, geographically as well as socially.

How close the other notables actually were to Kellis remains unknown. While Faustianos was in Hibis, Harpokration and Gelasios may have retired to the village (or its vicinity) after the end of their service, and Pausanias may even have resided there while officiating. ${ }^{27}$ Still, the Pamour family are only seen to have had direct ties to the family of Pausanias, and neither he nor Pisistratos were intimate associates. The social distance was likely too large: members of the curial class were not everyday associates of people of the family's standing. Nonetheless, being able to call on such men for favours, for instance in judicial matters, would have been of great importance. These ties to the elite of the Great Oasis would have been vital for the family - and the religious community when manoeuvring the Roman power structure.

\section{The Village Elite}

\subsection{Ploutogenes son of Ouonsis}

These high and mighty notables were not the only prominent figures in the village. Among the associates of the Pamour family we can discern another elite group, namely those wealthy villagers who were (at least in theory) obliged to

25 For Tehat, see КАв 106, 1264-1265; for freight payments to a group of people identifiable with associates of the Pamour family (including Kapiton, Papnouthes, and Psais), 12991315. Pekysis may make an appearance, as an agent working with Sarapis in KAB 1691. See the discussion of the Sarapas circle in Chapter 6.

26 For Elias, see P.Kellis I Gr. 68, 75, 78, and 81. The brothers from the Psais/Andreas circle are greeted in P.Kellis I Gr. 75, while a Pekysis and a Psais (presumably III) interact with him in P.Kellis I Gr. 68. These letters evince ties to the KAB, pointing to an identification of the landlord with Faustianos. Most notable is Siris, a tenant who pays dates in the KAB (l.1430) and owes dates in P.Kellis I Gr. 78. One may further compare the preoccupation with Mesobe in P.Kellis I Gr. 68 to that of the КАв manager (ibid., 73-74).

27 For the retirement of officials from cities to villages in the Roman period, see Andrea Zerbini, 'Human Mobility in the Roman Near East: Patterns and Motives', in Migration and Mobility in the Early Roman Empire, ed. Luuk de Ligt and Laurens E. Tacoma (Leiden: Brill, 2016), 328-29. 
undertake its most important and expensive liturgies. In contrast to the more distant notables, we would expect these to have a larger presence in the private material and be more central to the peer network of the family, an expectation borne out by the material.

P.Kellis I Gr. 24, an oath-declaration drawn up in 352, provides a good starting point for identifying other leading figures. As discussed in Chapter 2 (Section 3.2), it concerns a conflict between two men, Ploutogenes and Hatres, whose point of contention is lost. Luckily, the list of signatories is largely preserved. It is divided into four groups, each subscribed for by a competent writer, and features in total about 33 names, of which 26 can be read, as a rule accompanied by a patronymic. It thus provides a snapshot of a large group of prominent male villagers in Kellis in the middle of the fourth century. How big a percentage of the local elite they constituted, and exactly how prominent they were, is unknown. But the Ploutogenes in question is probably the son of Ouonsis, one of two komarchs of Kellis in P.Kellis I Gr. 23, and so the conflict revolved around a central actor in the village hierarchy. ${ }^{28}$ Admittedly,

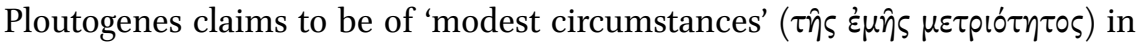
that document. However, this should not be taken to mean that his family was poor, by any means. About a generation earlier, in 319-320, an Ouonsis financed the purchase of transport animals for a trade venture to the Nile Valley, with the then-respectable sum of 12 talents. ${ }^{29}$ The name Ouonsis is not otherwise known in Kellis, so he is very likely Ploutogenes' father. The number of signatories to the oath in P.Kellis I Gr. 24 shows that Ploutogenes himself was a man of considerable local influence. That he had some kind of link to the Pamour family is implied by the finds of other documents pertaining to him among the Greek material in both House 2 and $3 \cdot{ }^{30}$ Still, they do not feature him interacting directly with members of the Pamour family, and, as in the case of Ploutogenes son of Petesis, the name is too common to trace him in the Coptic material, in the absence of other evidence.

\subsection{Psais Trpyhanes, the Loudons, and Psenpnouthes}

More certainty can be gained when we turn to the first group of signatories to the declaration. The group is headed by three clergymen not otherwise identifiable

28 P.Kellis I Gr. 24 features a '[son of] Ouonsis' (l.3), whose name is lost, and an 'aforementioned' Gena (short for Ploutogenes) (ll.7-8). Worp is hesitant with identifying the two (P.Kellis I, 74), but the contemporaneity of the documents, and prosopographical links between them, make an identification of the two Ploutogenes probable.

29 P.Gascou 18 and 19, see Bagnall, 'Two Partnership Agreements'.

30 A fragmented contract, P.Kellis I Gr. 18, and traces in P.Kellis v Copt. 47. 
in the House 1-3 material. ${ }^{31}$ Thereafter follow four men: Psenpnouthes, Psais Tryphanes, Timotheos son of Loudon, and Loudon son of L[oudon?], signed for by Sarapammon son of Psais. Their occurrence here is unlikely to be accidental: presumably they were, after the clergy, the most prominent men on the list. Of these, the name Psais Tryphanes recurs frequently in the House 3 material. ${ }^{32}$ Pekysis calls him 'father' in P.Kellis VII Copt. 78 , showing him to be a respected associate. While Psais Tryphanes primarily features in the Pamour/ Pekysis circle, a son of his named Tryphanes also occurs in the Maria/Makarios and Horion/Tehat circles. ${ }^{33}$ Their family was involved in various aspects of the Pamours' business: freight, textiles, and trade. In P.Kellis I Gr. 73, a letter from Psais Tryphanes to Pamour III, he asks Pamour to help out his son Tryphanes with selling goods, likely textiles. This shows a high degree of trust between the two. Sending one's children to fellow artisans for training in a craft was not unusual, as evinced by contracts for apprenticeships found in the papyri, ${ }^{34}$ but although Psais Tryphanes mentions 'wages' ( $\mu 1 \sigma \theta$ ós), their arrangement was clearly more informal. Ties between the Pamour family and Psais Tryphanes went beyond purely economic ones.

The subsequent two figures on the list, Timotheos and Loudon, are similarly found as business associates of the Pamour family in the Coptic material. They were perhaps brothers: Timotheos and Loudon II, sons of Loudon I. Timotheos is a common name in House $\mathbf{1}^{-} \mathbf{3}$ and Kellis at large, and tracing him on his own is difficult. Loudon, on the other hand, is rare. It is not attested outside of House $1-3$, and, in fact, only elsewhere found in Tehat's letter P.Kellis V Copt. 50, although variant forms of this name - Louitoni, Loutou, and Toni/ Tone - occur in a few other texts. ${ }^{35}$ P.Kellis v Copt. 50 involves both figures, as Tehat greets from Loudon and immediately after to(?) Timotheos 'son of Toni'. Tryphanes, too, is present with Tehat and Loudon, providing another link to P.Kellis I Gr. 24. The relationship of these two figures to Tehat involved business dealings, as she discusses a payment of barley(?) by Timotheos (amongst others) in the following lines. Their involvement in the family's business went

31 These are: Paminis the presbyter and two deacons, Pkour[..]s and Cholos.

32 P.Kellis I Gr. 50, 71, 73, P.Kellis viI Copt. 78, and possibly 112. The latter, a letter addressed to a Psais, was written on the recto of the private receipt P.Kellis I Gr. 50, and probably prior to that text; P.Kellis VII, 230-31. It is likely that Psais Tryphanes reused a letter he had received for the receipt, not least in light of the fact that P.Kellis viI Copt. 112 contains greetings to a 'father' Toni (i.e. Loudon, see below).

33 P.Kellis v Copt. 26, 50, and P.Kellis I Gr. 73.

34 Venticinque, 'Family Affairs: Guild Regulations and Family Relationships in Roman Egypt', Greek, Roman and Byzantine Studies 50 (2010), 288-92.

35 P.Kellis v Copt. 37, 47, 50; P.Kellis viI Copt. 78, 112. See P.Kellis V, 48. 
beyond Tehat: in P.Kellis v Copt. 37, Psais III is asked to procure wool from Louitoni by a certain Ammon - himself a close business associate, a warehouse owner located in Psbtnesis, and a Manichaean. ${ }^{36}$

Finally, we turn to Psenpnouthes, the figure who heads this group. He is less easy to place, both due to the commonality of the name in the Christian era, and the loss of the short title/patronym attached to it in P.Kellis I Gr. 24. A man by this name, husband to Kyria (I), appears in the Coptic texts as 'brother' to Makarios, and 'father' to Matthaios and Maria II. As such, it is likely that he was a relative of Pamour III's in-laws. Makarios consistently greets him first in his letters, even though he does not address him, presumably as a sign of respect. He also had an interest in textiles, indicated in Matthaios' P.Kellis v Copt. 26, and might be identified with a man of this name involved in Tehat's workshop. ${ }^{37}$ Decisive evidence for identifying this man with the one in P.Kellis I Gr. 24 is lacking, but circumstantial evidence points in this direction: the dating of the declaration fits well with the Maria/Makarios circle, he is a figure of some stature in both, and the man in the declaration is associated with men who can definitely be shown to be close business associates, Psais Tryphanes and the Loudons. While less secure than the others discussed, the identification does not seem unlikely.

\subsection{Pebos and Horion, Sons of Tithoes}

The second group of signatories to P.Kellis I Gr. 24 also provides some figures of local influence and close ties to the Pamour family. It is subscribed for by Pamour III, and so we might expect close associates of House 3 , but only the two brothers who head the group can be identified as such: Pebos and [Ho] rion, sons of Tithoes. These were important figures in mid-fourth century Kellis. Both were supporters of the komarch Ploutogenes son of Ouonsis in his conflict with Harpokration the ex-magistrate in P.Kellis I Gr. 23. Here, Pebos is said to have disarmed Harpokration's nine 'henchmen', for which he must have been able to mobilise assistants of his own, while Horion witnessed on behalf of Ploutogenes. Horion later occurs in the KAB: not as a regular tenant, but as providing a sizable amount of hay in a specific transaction (KAB 241-42). The brothers, then, must have been landowners of some means and stature in Kellis. That they had strong ties to the Pamour family is evinced by several

$36 \quad$ Based on his identification with Ammon the warehouse-owner in P.Kellis v Copt. 44 and 46 (note his recurring connection with a stikharion). Whether he, in turn, should be identified with an associate of Makarios by this name is unknown. For his religious affiliation, see Chapter 6, Sections 2.3 and 4.2. For Loudon II, see P.Kellis v Copt. 47.

For his link to Tehat, see P.Kellis v Copt. 48, as well as their shared ties to Tithoes I. 
contracts made in Aphrodito, which Pebos son of Tithoes drew up on behalf of family members. ${ }^{38}$ The ties may well have been closer, considering that he at this point had settled in Aphrodito, as had central members of the Pamour family. Both the names Pebos and Horion also occur in the Pamour family's Coptic material. For instance, a 'brother' Pebos travelled from Pamour III in Aphrodito to Pekysis in Kellis per P.Kellis vir Copt. 66, ${ }^{39}$ while Horion was, as we have seen, a key affiliate of Tehat and Horos $\mathrm{I}^{40}$ Identifying the two Horion's, in particular, would have a great impact on our understanding of this correspondence. But while possible, the evidence remains insufficient, and there are other possible identifications.

\section{$4 \quad$ Villagers in the Valley}

Not all the associates of the House 3 circles are found in the village itself: several Kellites had gathered in the village of Aphrodito in the Valley in the mid-fourth century. Among these, as we saw, were members of the Pamour family, such as Psais II and Pamour II, but also affiliates such as Pebos son of Tithoes. The contracts he drew up on behalf of family members feature other Kellites who had moved to the Valley. P.Kellis I Gr. 44 describes the creditor, a man named Antoninus, as formerly from Kellis but now residing in Aphrodito, while P.Kellis I Gr. 42 names Sofia, daughter of Besas, who received a loan from Pamour II, as likewise a former Kellis inhabitant. The same is said of Aurelia

38 P.Kellis I Gr. 42 (364), 43 (382), and 44 (374/87?). An obstacle to identifying this Pebos son of Tithoes with the man in P.Kellis I Gr. 24 is that Pamour III employs the formula 'because they do not know letters' (l.15), suggesting that this man lacked a high level of Greek literacy. However, writers were not always careful about the formula's accuracy, especially in lists; see Herbert Youtie, 'Because They Do Not Know Letters', Zeitschrift für Papyrologie und Epigraphik 19 (1975): 107. Given that Pamour III subscribes for altogether nine men, it is more attractive to take the formula here as a stock phrase, presumably valid for most but not all those listed, than to assume that there were two Pebos son of Tithoes, associates of Pamour III, from mid-fourth century Kellis.

39 See perhaps also 'brother' Pebos writing Psais III in P.Kellis viI Copt. 111, or 'father' Pebos featuring in P.Kellis viI Copt. 120. Both of these were involved in text production, which fits with this man. An identification with one or more of these would tie Pebos son of Tithoes closely to the Manichaean community, but see Chapter 9, Section 2.3.

40 A possible connection may be found in P.Kellis I Gr. 14 (356), where N. N., 'son of Tithoes', writes on behalf of a Horion. It is possible to restore the former name as 'Pebos', while the latter is likely to be identified with the man in the Coptic correspondence. However, the patronymic 'son of Tithoes' here has a different form than that found in the other documents of Pebos, and so restoration of his name is not a given, see P.Kellis I, 43 . 
Marsis, who rented a room from Psais II in Aphrodito in P.Kellis I Gr. 32. Both P.Kellis I Gr. 42 and 32 date to the year 364 . The contemporary Coptic letters hint at a wider, Aphrodito-based network as well. In P.Kellis VII Copt. 9o, the author, a certain Apa Psekes, mentions that he has resided at a location away from Kellis - probably Aphrodito, although the name must be restored for 20 years. He also mentions a large sum of money (six solidi), half of which he had received from his 'father' Ploutogenes in Kellis, showing continued interaction with his home-village. ${ }^{41}$

Kellites in Aphrodito, then, continued to do business among themselves. It is likely that they maintained a degree of collective identity and strong ties to their hometown. Oasites certainly considered themselves distinct from 'Egyptians', i.e. Valley dwellers, and there may be traces of a more specific village identity in the evidence. Psais III seems to hint at such an identity in a passage from P.Kellis vir Copt. 105, where he writes: 'indeed, I, my brothers, I want to come to the Oasis for these very seasons; if you reach me anew and I forget my village' (ll.43-46). Although the phrase is not without difficulties of interpretation, ${ }^{42}$ Psais seems to be expressing a strong wish to return so as not to forget his home. For comparison, one may consider a third-century letter from Oxyrhynchus, P.Oxy. XXXI 2595. Here a Horigenes writes his brother Serenos (presumably in Oxyrhynchus) asking him to come, adding: 'You will do well to come to us for a few days, for there are many Oxyrhynchites here' (ll.5-7, trans. Adams). As Adams points out, it shows that a sense of collective identity existed among 'diaspora' Oxyrhynchites. ${ }^{43}$ Thus, while Pamour III and his family may have been trying to integrate and become 'Egyptian', as they are labelled by the scribe of P.Kellis I Gr. 30, many of their contacts were still fellow-villagers. It is clear that we should not think of the Pamours' interaction with the Valley as that of an isolated family and their relatives, but as part of a larger mobilisation of Kellites.

41 Two other contemporary documents from House 3 could relate to him: a 'father' Psekes travelled with 'father' Pishai from Antinoopolis to Kellis in Matthaios' letter P.Kellis V Copt. 25, and a 'father' Psekes, presbyter, witnessed a manumission on behalf of Valerios son of Sarapion in P.Kellis Gr. I 48 (dated 355). See Chapter 8, Section 3.4.

42 See P.Kellis VII, 206.

43 For translation and remarks, Colin Adams, 'Migration in Roman Egypt: Problems and Possibilities', in Migration and Mobility in the Early Roman Empire, ed. Luuk de Ligt and Laurens E. Tacoma (Leiden: Brill, 2016), 277-78. 
To sum up, the Pamour family had strong social and economic ties with leading families in Kellis and retained contact with fellow-villagers in the Valley. This network included prominent villagers, such as Psenpnouthes I, Psais Tryphanes, and Pebos son of Tithoes. Many other affiliates, occurring primarily in the Coptic material, can be added to those discussed above, such as 'father' Antinou, 'son' Lammon, and 'brother' Papnouthes.

The question of how this network is to be understood remains to be addressed. In particular, we should consider whether we could be dealing with

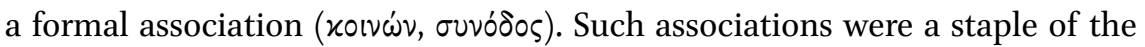
ancient world, and a broad phenomenon, ranging from those devoted to spe-

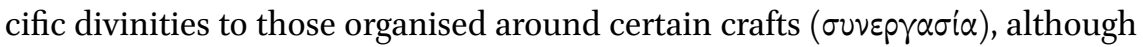
no association had only one function..$^{44}$ Occupational associations hosted regular gatherings, collected membership fees, kept accounts of shared expenditures, had formal leaders, and assisted members in economic matters. ${ }^{45}$ Scholarship has long emphasised associations' role as 'social clubs', as substitutes for people who lacked the security provided by kinship ties. Some recent works have argued that this emphasis downplays the economic functions of occupational associations. ${ }^{46}$ Thus Philip Venticinque has argued that associations complemented rather than replaced ties of kinship, helped members absorb economic hardship, and strengthened mutual business ties. ${ }^{47}$ Their role as 'social clubs' was in other words important also economically.

Going back to the Kellites, it must be stressed that there is no direct evidence for a formalised trade association in the documents so far published. Any argument for such a framework must be indirect. That said, some circumstantial evidence can be adduced. For one, there is the close cooperation

44 Harland, Associations, 25-53. Building on the work of Kloppenborg, Harland follows a typology of associations based on membership rather than purpose or 'function'; dividing between associations primarily based on 1) household, 2) ethnic/geographic, 3) neighbourhood, 4) occupation, and 5) cultic connections. Of these, the Kellis association - if this is what it was - would primarily have been a professional association (ibid., 38-44), although household members, geographic factors, and cult (as we shall see in Chapter 6, Section 2.3) were all constitutive elements.

45 Venticinque, 'Common Causes: Guilds, Craftsmen and Merchants in the Economy and Society of Roman and Late Roman Egypt' (Ph.D., University of Chicago, 2009), 54-67, 213.

46 Harland, Associations, 59-61; Venticinque, 'Common Causes', 24-54; id., 'Family Affairs'; Matt Gibbs, 'Trade Associations in Roman Egypt: Their raison d'être', Ancient Society 41 (2011).

Venticinque, 'Family Affairs', 292-94. 
between different familial groups. ${ }^{48}$ The affiliation with figures such as Loudon and Psais Tryphanes shows that the group included families outside the extended kinship group. It could be objected that their activities involved weavers as well as traders, women as well as men, somewhat at odds with the norm of single-occupation, male-only associations. On the other hand, little is known about the way textile production was organised within trade associations, and it seems likely that such cooperation must have been common..$^{49} \mathrm{~A}$ formal framework would be strongly supported if, as has often been supposed, membership in occupational associations became compulsory for traders and artisans at the time of Diocletian, but this has been challenged by among others Adriaan J. B. Sirks, and the debate is still ongoing. ${ }^{50}$ Nonetheless, it does seem that the late Roman state preferred to collect taxes, especially the chrysargyron tax, by way of occupational associations, ${ }^{51}$ and there is some tentative evidence for such collective payments from House $1-3 .{ }^{52}$

We cannot know for sure whether the traders of Kellis were organised as a formal association or not - if so, its documents must have been stored elsewhere. The absence of strong evidence should caution us against assuming a formal framework. At any rate, the papyri do show that the Pamour family cooperated closely with fellow-traders from Kellis outside their own kinship group, and participated in a large trading group that shared resources, used common storehouses, and supported each other in selling goods. This larger 'trust network' would have assuaged some of the risks, deflected losses, and made it possible for the Pamour family to participate in the markets of the Nile Valley.

\footnotetext{
$48 \quad$ Ibid., 276.

49 See Gibbs, 'Trade Associations', 294; Harland, Associations, 38.

$50 \quad$ A. J. B. Sirks, 'Did the Late Roman Government Try to Tie People to their Profession or Status?', Tyche 8 (1993); Venticinque, 'Common Causes', 188-90, and 205-6.

51 Venticinque, 'Common Causes', 180; Gibbs, 'Trade Associations', 292.

$5^{2}$ A letter by Pekysis to a 'brother' Sarapis, P.Kellis I Gr. 76, may pertain to such a collective payment. Sarapis is waiting for a payment of the chrysargyron tax. That Pekysis titles him 'brother' may suggest that Sarapis is not a formal tax official, but a fellow-trader responsible for collecting taxes. For kinship terms in associations, see Harland, Dynamics of Identity, 63ff; for the guild official ( $\dot{\varepsilon} \pi \sigma \tau \dot{\alpha} \tau \eta \varsigma)$ elected to collect taxes in associations, see Venticinque, 'Common Causes', 204. Similarly, a tax payment by Philammon I and Pamour I documented in the receipt O.Kellis I 4 seems to have been on behalf of a collective, and could conceivably imply that they acted as representatives of a trade association. See O.Kellis I, 34 .
} 
Instead of trying to pin down a formal organisation, then, we need to continue our relational investigation. To conclude the chapter, we examine the informal social ties in Kellis through quantitative social network analysis, following the methodology used by Ruffini in his analysis of the network of sixth-century Aphrodito. ${ }^{53}$ This approach furnishes us with a fuller sense of the Pamour family's network. As we shall see, it can also highlight actors, peripheral (or even invisible) in the House 3 material, that may yet be of great interest for understanding the local Manichaean community. Below, we examine some network representations of the textual material from Kellis, and consider their implications for the social world of the Pamour family. By using a database of the texts from Kellis and the actors they feature, we trace relationships between actors through the whole body of relevant texts, and analyse the connectivity of the village network, and the centrality of certain actors, in statistical terms.

The present network is constructed from a dataset of close to 6oo texts. House 1-3 was the single largest find spot, but the dataset includes finds from the whole village. ${ }^{54}$ From it has been extracted a second dataset of around $175^{\circ}$ actors. Texts and actors are assigned ID-numbers and other attributes, such as 'Type' (either 'text' or 'actor'), and stored in an excel spreadsheet. Another sheet, a so-called edge-list, links actors to the texts in which they appear. These sheets are then uploaded into Gephi, a free social network analysis software, which generates a so-called two-mode, or actor-to-text, network. ${ }^{55}$ Next, all but those texts dating from the period under consideration, i.e. mid- to late fourth century, are removed, leaving a network of 230 texts with 554 agents. Finally, this two-mode network is transformed into a one-mode network, linking actors directly to those actors connected to the same texts, with the help of a plug-in for Gephi called 'MultiMode Network Projection'. Various statistical

53 See Ruffini, Social Networks, 198-241. For a more comprehensive version of the present analysis, see Teigen, 'Limbs', chapter 5 .

54 Of the 598 documents in the database, 347 texts $(c .6 \circ \%)$ were not from House $1-3$. The other primary site was the Main Temple, with its associated shrines $(\mathrm{D} / 1-4,150$ texts). The West Church (D/6, 53 texts) was another important find-site. Smaller finds came from a rubbish heap (A/10, 30 texts) and from domestic settings: houses in area $\mathrm{C}\left(\mathrm{C}_{1}\right.$ and $\mathrm{C} 2,37$ texts), structure D/8 (D/8, 31 texts), House 4 (A/6, 24 texts), and House 5 (A/8-9, 5 texts). A few ostraka were found in the East Church $(\mathrm{A} / 7,9$ texts), while the large block in Area B $(\mathrm{B} / 1)$ has only yielded three jar dockets so far. In addition, 5 texts of unknown provenance within the village have been included.

55 For these tables, see: http://hdl.handle.net/1956/18580. Gephi has been chosen for its accessibility and for being freely available. A more popular software is UCINET/Pajec; for these, see Ruffini, Social Networks, 29-30. 
tools allow us to consider both the characteristics of the network as a whole, and the centrality of individual actors within it. Important statistical measures for the network as a whole are density, diameter, and average path length. ${ }^{56}$ In examining the centrality of actors within the network, on the other hand, one can employ measures such as degree centrality, closeness centrality, and betweenness centrality. ${ }^{57}$ It is the last measure, that of betweenness centrality, which primarily concerns us here. It rates node 'accessibility', scoring them according to how often they appear on the shortest paths that other nodes have to take in order to reach each other - i.e. which actors are most important as bridges between different sub-groups. The charts presented below portray the relative betweenness centrality score of the actors by way of size: the more central an actor, the larger he/she is shown on the chart.

Some important limitations need to be noted. A common criticism of social network analysis on historical sources is that the centrality detected is an artifice of these same sources, rather than reflective of historical reality. In the case of the Kellis material, this causes actors from the House 1-3 texts to appear much more central than they were due to the accidental survival of their archive - especially the body of private letters, which are mainly concerned with matters internal to the family. Furthermore, it may be objected that the approach gives a misleading picture of those interactions that are visible, as people are linked merely for occurring together in the same document, subsuming different types of interaction under 'connection'. To this it may be countered that, with regards to the first point, our interest is with the relationship between the Pamour family and the rest of the village, rather than a bird's eye view of the village as a whole, to which the Pamour archive remains indispensable. Moreover, we can to some extent account for the bias of family affairs by considering an iteration of the network where we exclude the private letters from House 3 .

As to the second point, it is true that a more fine-grained method for interaction could have been used, distinguishing between different forms of interaction, and adding directionality or positive/negative values to ties. But the model is not meant to be an accurate picture of social hierarchies in the village, but to highlight actors who were often active in different social circles, and

$5^{6}$ Density measures the number of actualised ties relative to that of possible ties between the nodes, i.e. the network's degree of connectedness. Diameter shows how many ties there are between the two nodes that are furthest apart; i.e. the longest distance from one 'end' of the network to the other. Average path length shows the average amount of ties that one randomly chosen node has to pass through in order to reach any other.

57 Degree centrality measures the total amount of connections. An actor's rank depends on the number of texts (s)he occurs in and how many other actors occur in the same texts. Closeness centrality is a measure of which nodes have on average the shortest path to all the others, being closest to the 'centre' of the network. 
who only appear when the whole body of material is considered. While admittedly a blunt measure, co-occurrence does imply 'connection of some sort', as Ruffini has put it (italics in original). ${ }^{58}$ It allows us to detect actors who were well-positioned to, for instance, mediate, broker deals, spread information, or distribute resources, as far as the evidence allows us to map them. To be sure, the specifics of an actor's role have to be considered individually. There are also co-occurrences that do not imply social links at all. Ruffini pointed out the problem of leaving large 'event documents', such as fiscal registers, in the database. ${ }^{59}$ They contain a large number of actors, but do not imply any actual familiarity or interaction between most of them, and so have to be removed. For this reason, the only large event document from Kellis, the KAB, is removed from the present analysis. The same objection can be made for smaller accounts, lists, and even some letters. ${ }^{60}$ At the same time, some accounts and lists do imply or presuppose interaction - e.g. dekania lists, ${ }^{61}$ priest lists, and some accounts. The analysis therefore examines network iterations both excluding and including smaller accounts/lists, so that the difference can be appraised. ${ }^{62} \mathrm{~A}$ final issue that needs to be accounted for is difficulties in making prosopographic identification. The centrality of an actor can sometimes shift drastically depending on whether he or she is identified as present in a certain document. On the one hand, occurrences of names may be mistakenly attributed to one actor, inflating his or her centrality; on the other, the absence of identification may cause us to underestimate an actor's centrality. The edge list therefore assigns a certainty value to each link between actors and texts. ${ }^{63}$

In order to account for these limitations, then, we shall consider three iterations of the village network. The first is generated from all 230 texts, dating roughly 320-39o, and features 554 actors. In order to control for the bias of the Pamour archive, a second iteration excludes all the private letters from House 3. Finally, a third iteration excludes both accounts/lists and House 3

$5^{8}$ Ruffini, Social Networks, 25 .

59 Ibid., 203-4.

6o See for instance Brand, 'Speech Patterns', 109.

61 For dekania lists, i.e. lists of villagers drafted for guard duty, see Roger S. Bagnall, 'Army and Police in Roman Upper Egypt', Journal of the American Research Center in Egypt 14 (1977). For such lists from Kellis, see O.Kellis I 124-137, P.Kellis I Gr. 6o.

62 For dekania lists, i.e. lists of villagers drafted for guard duty, see Roger S. Bagnall, 'Army and Police in Roman Upper Egypt', Journal of the American Research Center in Egypt 14 (1977). For such lists from Kellis, see O.Kellis I 124-137, P.Kellis I Gr. 6o.

63 From o to 6, using a scale of decreasing certainty. The 'core' occurrence of an actor is designated $o$. Next, 1 is a certain identification with actor $0 ; 2$ an all but certain, 3 a very likely, 4 a likely, 5 an uncertain, and 6 a tenuous identification. Evaluation criteria are: patronymics, find spot, rarity of the name, presence of shared actors, dating, and the activity that the actor engages in. The networks below are based on those links considered 'likely'. 
letters. The actors who recur in all these lists are more likely to actually have been central in some way. In our analysis, we draw attention to some general features of the network, and what they may tell us of village connectivity, and we end by discussing some recurring actors more closely. As we shall see, we have already met most of them, but there are also two previously unnoticed figures that score high in the networks, and who are of significance for the local Manichaean community.

\subsection{Network Charts and Tables}

$\begin{array}{lll}\text { All documents } & \text { Excluding } \mathrm{H}_{3} \text { letters } & \text { Excluding } \mathrm{H}_{3} \text { letters and } \\ (\text { Chart } 1) & (\text { Chart 2) } & \text { accounts/lists (Chart 3) }\end{array}$

\begin{tabular}{llll}
\hline Components & 26 & 28 & 37 \\
(non-isolates) & $(18)$ & $(24)$ & $(29)$ \\
Actors & 554 & 393 & 257 \\
Average path length & 3,514 & 3,822 & 3,114 \\
Density & $2,50 \%$ & $2,40 \%$ & $3,20 \%$ \\
\hline
\end{tabular}

Giant component

\begin{tabular}{llll}
\hline Actors & 489 & 301 & 145 \\
Average path length & $3,5^{2}$ & 3,848 & 3,122 \\
Density & $3,10 \%$ & $3,70 \%$ & $8,80 \%$ \\
Diameter & 9 & 9 & 9 \\
\hline
\end{tabular}

\section{Top ten names}

\begin{tabular}{|c|c|c|c|}
\hline \multirow[t]{13}{*}{ Degree centrality } & Pamour III (5073) & Horion s.Tithoes (109o) & Horion s.Tithoes (1090) \\
\hline & Philammon II (5051) & Pamour III (5073) & Pebos s.Tithoes (1091) \\
\hline & Psais II $(5 \circ 89)$ & Pebos s.Tithoes (1091) & Ploutogenes s.Ouonsis \\
\hline & Psenpnouthes (5010) & Ploutogenes s.Ouonsis & $(5155)$ \\
\hline & Andreas $(5 \circ \circ 8)$ & $(5155)$ & Pamour III (5073) \\
\hline & Kapiton I (1014) & Psenpnouthes I (5010) & Pataias (1011) \\
\hline & Lammon (5057) & Pataias (1011) & Kapiton I (1014) \\
\hline & Pekysis $(5 \circ 81)$ & Kapiton I (1014) & Psenpnouthes I (5010) \\
\hline & Psais III (1264) & Sarapammon s.Psais & Sarapammon s.Psais \\
\hline & Charis $\left(5^{\circ} 5^{2}\right)$ & $\left(105^{2}\right)$ & $\left(105^{2}\right)$ \\
\hline & & Loudon II (5110) & Pinoutas s.Ploutogenes \\
\hline & & Tehat (5035) & $(1016)$ \\
\hline & & & Psais s.Peteminis (1012) \\
\hline
\end{tabular}




\begin{tabular}{|c|c|c|c|}
\hline & $\begin{array}{l}\text { All documents } \\
\text { (Chart 1) }\end{array}$ & $\begin{array}{l}\text { Excluding } \mathrm{H}_{3} \text { letters } \\
\text { (Chart 2) }\end{array}$ & $\begin{array}{l}\text { Excluding } \mathrm{H}_{3} \text { letters and } \\
\text { accounts/lists (Chart 3) }\end{array}$ \\
\hline Closeness centrality & $\begin{array}{l}\text { Pamour III (5O73) } \\
\text { Psenpnouthes I (5010) } \\
\text { Psais II (5089) } \\
\text { Horion s.Tithoes } \\
\text { (1090) } \\
\text { Lammon (5057) } \\
\text { Kapiton I (1014) } \\
\text { Partheni II (5087) } \\
\text { Hatres (5030) } \\
\text { Psais Tryphanes } \\
\text { (7036) } \\
\text { Tehat (5035) }\end{array}$ & $\begin{array}{l}\text { Horion s.Tithoes (1090) } \\
\text { Pebos s.Tithoes (1091) } \\
\text { Ploutogenes s.Ouon. } \\
(5155) \\
\text { Pamour III (5073) } \\
\text { Psenpnouthes I (5010) } \\
\text { Psais s.Tryphanes (7036) } \\
\text { Kome (4087) } \\
\text { Timotheos s.Harpokra- } \\
\text { tion (1035) } \\
\text { Pataias (1011) } \\
\text { Harpokration (1026) }\end{array}$ & $\begin{array}{l}\text { Horion s.Tithoes (1090) } \\
\text { Pebos s.Tithoes (1091) } \\
\text { Ploutogenes s.Ouonsis } \\
(5155) \\
\text { Pamour III (5073) } \\
\text { Pataias (1011) } \\
\text { Psenpnouthes I (5010) } \\
\text { Psais Tryphanes } \\
\text { Kapiton I (1014) } \\
\text { Sarapammon s.Psais } \\
\text { (1052) } \\
\text { Pinoutas s.Ploutogenes } \\
\text { (1016) }\end{array}$ \\
\hline $\begin{array}{l}\text { Betweenness } \\
\text { centrality }\end{array}$ & $\begin{array}{l}\text { Petros }(5036) \\
\text { Psais II }(5089) \\
\text { Pausanias s.Valerios } \\
(1017) \\
\text { Horion s.Tithoes } \\
\text { (1090) } \\
\text { Psenpnouthes I (5010) } \\
\text { Pamour III (5073) } \\
\text { Ammonios f.Psais } \\
\text { (8352) } \\
\text { Kapiton I (1014) } \\
\text { Tehat (5035) } \\
\text { Pisistratos (1175) }\end{array}$ & $\begin{array}{l}\text { Horion s.Tithoes (1090) } \\
\text { Petros }\left(5^{\circ} 36\right) \\
\text { Pausanias s.Valerios } \\
(1017) \\
\text { Pamour III (5073) } \\
\text { Kome (4087) } \\
\text { Ammonios f.Psais (8352) } \\
\text { Psais II (5089) } \\
\text { Pisistratos (1175) } \\
\text { Porphyrios (9508) } \\
\text { Psenpnouthes I (5010) }\end{array}$ & $\begin{array}{l}\text { Pamour III (5O73) } \\
\text { Psenpnouthes I (5010) } \\
\text { Pebos s.Tithoes (1091) } \\
\text { Pausanias s.Valerios } \\
\text { (1017) } \\
\text { Horion s.Tithoes (1090) } \\
\text { Gelasios (1261) } \\
\text { Psais II (5089) } \\
\text { Pataias (1011) } \\
\text { Harpokration (1026) } \\
\text { Tithoes I s.Petesis (5013) }\end{array}$ \\
\hline
\end{tabular}

\subsection{Models and Social Reality}

The part of the network dominated by the Pamour family is characterised by a high degree of connectivity and many possible routes for the dissemination of information. ${ }^{64}$ Thus, although Chapter 3 assessed the material in

64 For a more extensive examination of the network of House 1-3, see Teigen, 'Limbs', 13436. A similar result, based on a different network construction, is shown by Brand, 'Speech Patterns', 110. 


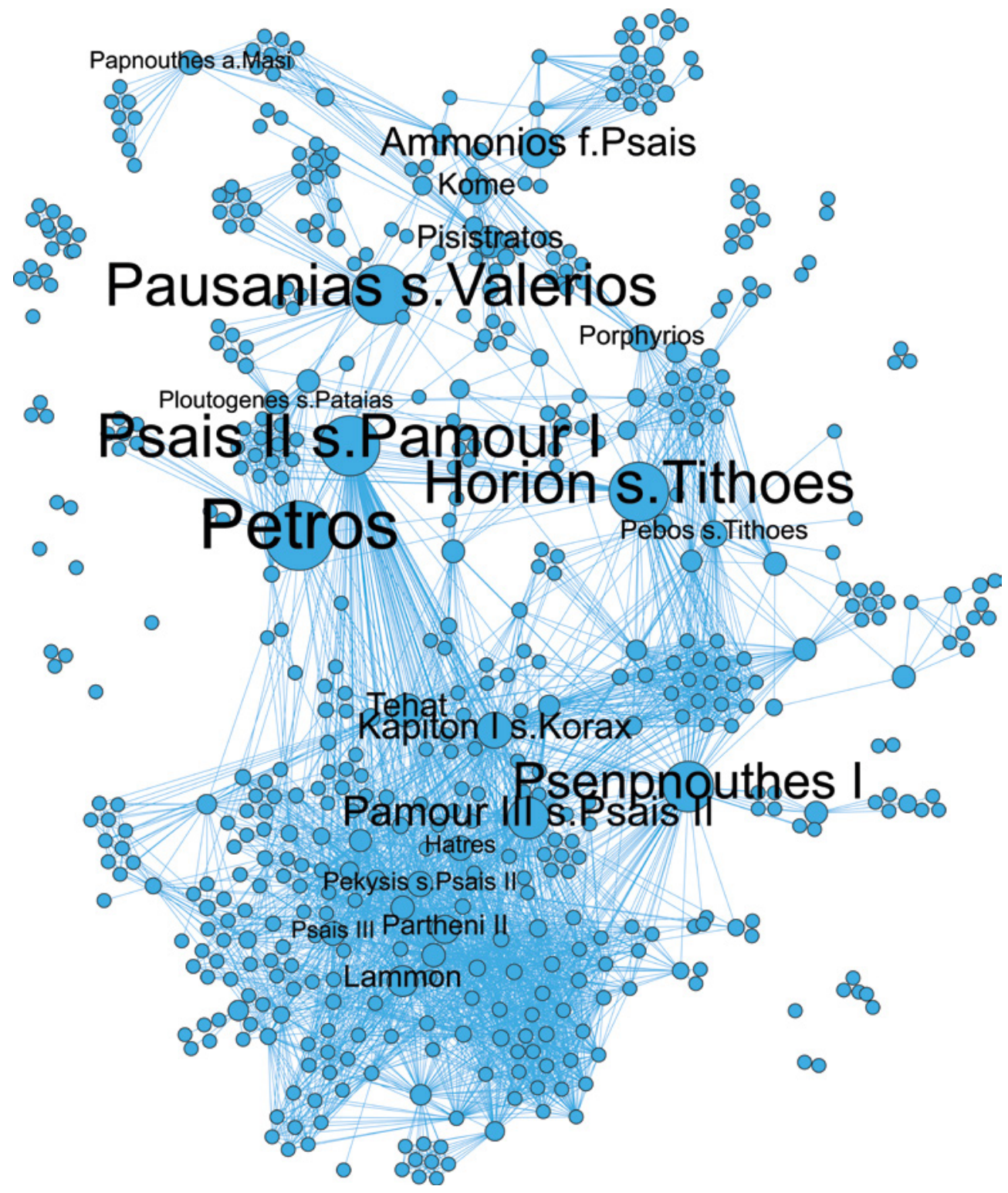

CHART 1 All documents

terms of different circles, the overlap between them is so extensive that they are hard to differentiate. Even circles presumed to be chronologically separate, such as Horion/Tehat and Psais/Andreas, are tightly connected. This gives weight to the hypothesis that the central House 3 circles belonged to a single kinship group whose material pertains to a relatively short time span. However, while the other parts of the network are less cohesive than that of 


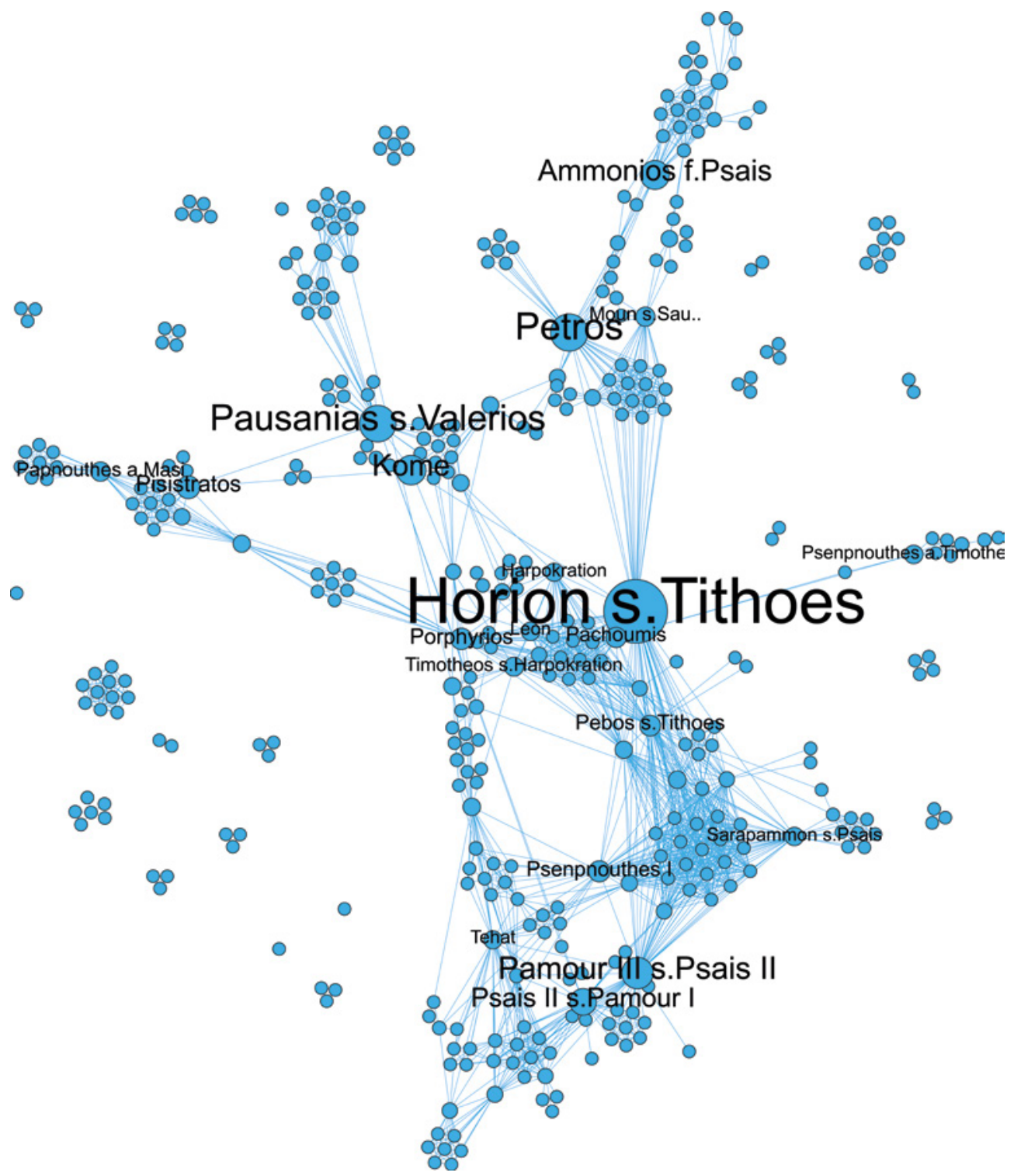

CHART 2 Excluding House 3 letters

the Pamour cluster, we cannot therefore conclude that the Pamour family was more tightly interconnected than 'normal'. It rather reflects the number and type of documentary texts (so far) published from other parts of the village, as discussed earlier. Similarly, the dominance of members of the Pamour family in centrality in Chart 1 does not reflect any hegemony by this group over the village. When the private letters from House 3 are removed, only a few of the 


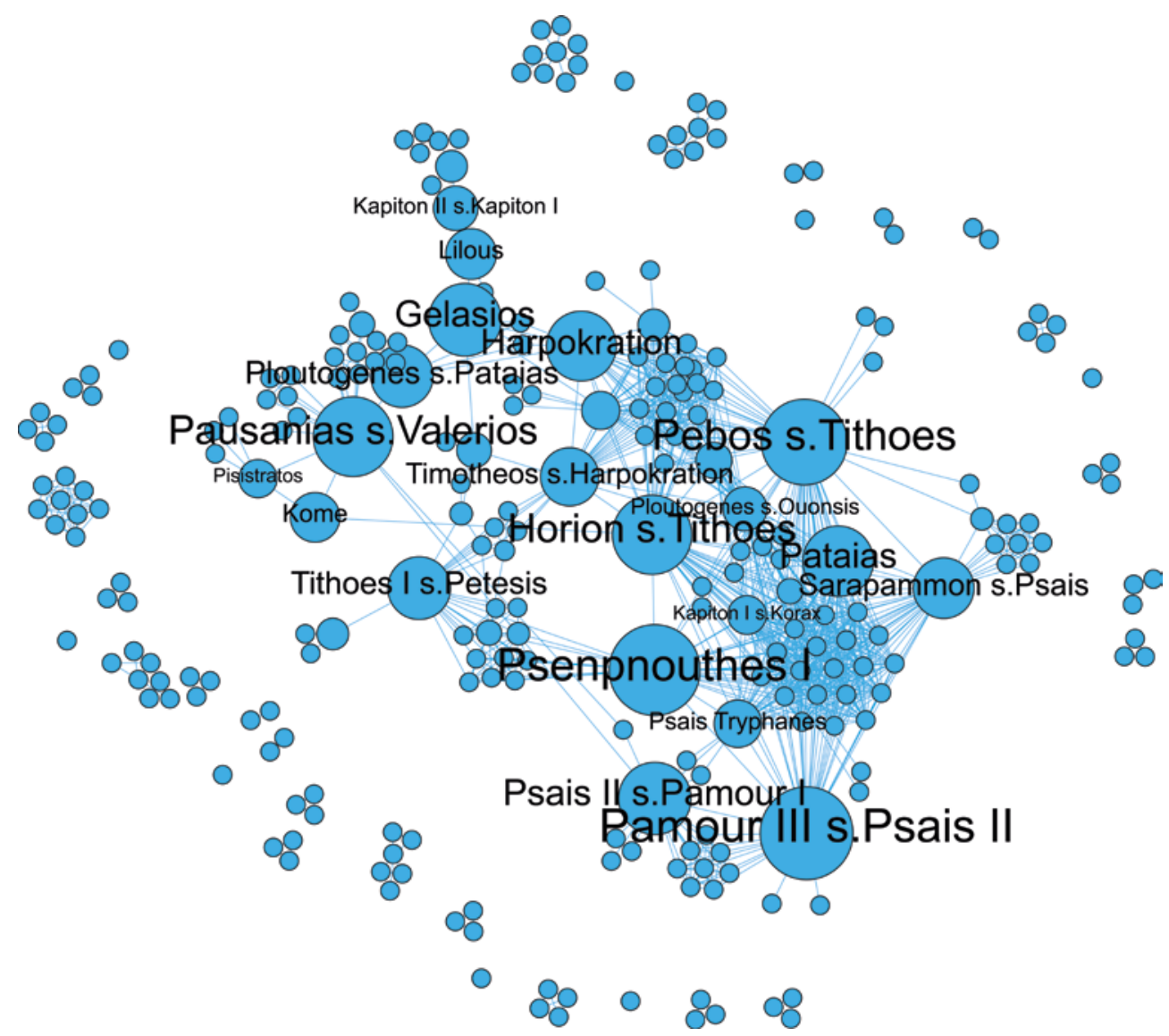

CHART 3 Excluding accounts and House 3 letters

main family members (Pamour III, Psais II) score high in terms of betweenness centrality, despite the fact that their archive still make up a sizable part of the total documents (see Chart 2).

Beyond the members of the family, we may note that several of their close associates appear with high centrality scores. In particular, there are several associates that remain prominent in all the network iterations: Pebos and Horion, sons of Tithoes, Pausanias the ex-magistrate, and Psenpnouthes I. As has been discussed above, these figures can be shown to have been of village-wide importance. Their centrality scores here do not necessarily imply that they were 'the' most important figures in the village, however, but highlight their role in mediating between the Pamour family and other circles in the village. There are, in fact, only a few figures that have not been discussed individually so far, namely Petros, Kome, Ammonios father of Psais, and Porphyrios. The 
two latter are of less interest: while they may have been important figures in other circles, their roles remain obscure. ${ }^{65}$ The two former, on the other hand, deserve closer attention. The figure of Petros is the primary recurring actor in the Petros letters, where the son consistently refers to him as 'our brother' and entrusts him with various messages and writings. The name occurs once in the House 1-3 material outside this circle, in Horion's letter P.Kellis v Copt. 18 to Horos I. His prominence in the network is based on an identification with a Petros that occurs in a group of West Church ostraka accounts, by way of the кав. The кав features a Petros 'the monk' who pays rents on behalf of a topos Mani, partly in olive oil.66 Similarly, O.Kellis I 121, an account of olive oil from the West Church, lists Petros and four other actors, one of whom is explicitly titled 'monk', and the others potentially identifiable as such. ${ }^{67}$ The name 'Petros' is not common in Kellis outside the West Church and House $1-3$, being only found once. It is likely that Petros, found in the KAB, the House 1-3 texts, and O.Kellis I 121, was a Manichaean Elect active in the village, who acted as a mediator between House 3 circles, large landowners, and a Manichaean religious institution. Based on find spot, relative rarity of the name in Kellis, and a similar role as a tenant, this man is further identifiable with Petros who occurs in a group of ostraka accounts from the West Church (O.Kellis I 114, 115, 117). This explains his position above. It may be objected that the identification of the monk with the man in these potsherds is less certain, and so his centrality could be inflated. Still, it is not unlikely that a religious authority with financial responsibilities would have featured prominently in village life.

Kome is another central figure not previously considered. While only occurring among the top ten in Chart 2, he is rated 12th in the iterations of Chart 1 and 3. He, too, occurs in ostraka from the West Church (and elsewhere), and can be identified by reference to the $\mathrm{KAB}$, where a man by this name is one of the largest and most important tenants. ${ }^{68}$ At times, he mediated on behalf

65 Porphyrios was an agent of Harpokration and an important associate of the author of P.Bingen 119, while Ammonios bridges some of the accounts from the West Church.

66 For the identification of Petros with this man, see Chapter 8, Section 1. For the topos Mani, see Chapter 9, Section 3.3.

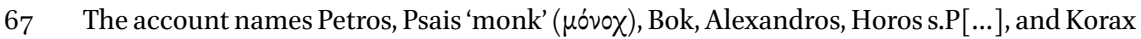
son of Tithoes. It is possible that the account lists a series of monks, Psais being the only one explicitly labelled as such. A presbyter named Psais is found in P.Kellis viI Copt. 92. For Bok, note Pebok, 'father' at a monastery in P.Kellis v Copt. 12; for Horos, the associate of Lysimachos in P.Kellis v Copt. 30 and P.Kellis viI Copt. 72; for Alexandros, perhaps 'Apa Alexandros' in an ostrakon from nearby 'Ain el-Gedida (see Aravecchia, 'Christians', 247).

68 There are two Kome's in the КАв; Kome the tenant and Kome the bath-man (ibid., 64). Kome the tenant acted several times as an agent for the КАв manager, and paid dues in wheat, hay, chaff, and chickens. This agrees well with the Kome from the ostraka, who 
of known actors: in O.Kellis I 85, a memo, Pausanias orders Kome to provide chickens for Pisistratos on the second indiction year (328/9, or perhaps $347 / 8)$. There is good reason to think that Kome's position in the network reflects his role as a relatively wealthy tenant farmer in the vicinity of Kellis. Furthermore, his relationship to Pausanias and to a monk named Timotheos tie him indirectly to the Pamour family, a point to which we return in Chapter 6 .

In the course of this chapter, we have situated the Pamour family in the village by sketching their ties to different circles. Although certainly not marginal, its members do not appear to have been the most prominent citizens of Kellis. Yet they had a diverse and extensive network of contacts, among whom many prominent figures can be discerned. This network included colleagues active in the family's business venture, weavers, traders and camel drivers, but also neighbouring carpenters, Oasis notables, local landowners, and other villagers who for unknown reasons had moved to Aphrodito in the Nile Valley in the mid - late fourth century. Prominent figures include, in particular, Pebos and Horion sons of Tithoes, a circle of traders tied to Psenpnouthes I and Psais son of Tryphanes, and the ex-magistrate Pausanias son of Valerios. Many of these relationships are, moreover, significant for understanding the Manichaean community in the village, as we shall see in Chapter 6. First, however, we need to examine what characterised this 'Manichaeanness' in the first place. It is to this matter that we now turn.

pays chicken to Pisistratos on behalf of Pausanias in O.Kellis I 85, who acts as an agent in O.Kellis I 112 from the same find site, who owes dues in hay or chaff in O.Kellis I 119 from House 4, and who delivers a large amount of fava flour (ten art.; for which cf. the amounts in the $\mathrm{KAB}$, P.Kellis $I V, 46)$ in O.Kellis I 6 o from the Main Temple, all from the fourth century. He was probably quite old by the 360 , as he had at least one grown son, Nos, according to the кав. Bagnall writes: largest tenant in indication 5 and indiction 6, afterward replaced by his sons Nos and Timotheos ... He may well have died early in the harvest of ind. 6.' P.Kellis IV, 68. The name also occurs in O.Kellis I 131, but is less securely relatable to this figure. 